\title{
A Study on Problems and Countermeasures in Mixed Ownership Reform of State-owned Enterprises
}

\author{
Xiaoling Zheng \\ ${ }^{1}$ School of Economics \& Management, Minjiang University, Fuzhou City, Fujian Province, 350108, \\ China
}

Keywords: State-owned Enterprises; Mixed Ownership; Reform; Problems; Countermeasures

\begin{abstract}
The State Council issued the Opinions on the Development of Mixed Ownership Economy in State-owned Enterprises on September 24, 2015, which pointed out that the development of mixed ownership economy is an important measure to deepen the reform of state-owned enterprises. It is necessary to promote the mixed ownership reform of state-owned enterprises and promote the common development of all kinds of ownership economies. In terms of the practice of reform and opening up in China, the mixed ownership economy has played an important role in deepening the reform of state-owned enterprises, improving the efficiency of resource allocation and enhancing the competitiveness of enterprises. This paper analyzed problems in mixed ownership reform of state-owned enterprises and put forward some suggestions to promote the mixed ownership reform of state-owned enterprises.
\end{abstract}

\section{Introduction}

For a long time, China has adopted the ownership system where the public ownership is the main body and various ownership economies develop jointly. In this ownership system, the combination of public ownership and non-public ownership is mainly a "plate type" combination model. They promote common development by influencing each other directly or indirectly on the basis of independent development. Practice has proved that there is a big limitation in this combination model. It is difficult for this system to effectively promote the common development of the public and non-public economies, which leads to the slow development of public ownership economy. In particular, state-owned enterprises are in inefficiency, which cannot promote the common development of non-public economy. Although the non-public enterprises develop rapidly and the efficiency is relatively high, the scale is small generally, so that they just can play a limited role in promoting the whole national economy. How to change this situation and make the public enterprises and non-public enterprises give full play to their development potential with complementary advantages to jointly promote the sound development of the whole national economy is an important issue faced by state-owned enterprises.

\section{Main Problems in Mixed Ownership Reform of State-owned Enterprises}

The problem on effective integration of state-owned enterprises and non-public capital. First, the goal is different. Most of the state-owned enterprises are profitable, but profit is not the only purpose. In the course of operation, state-owned enterprises emphasize social interests and long-term interests. Non-public capital has a clear ownership and the owner has self-management right and decision-making power in the enterprise. To maximize the benefit is its driving force for production and operation decisions. In the mixed ownership reform of state-owned enterprises, if the non-public capital is only a subsidiary of state-owned enterprises and the decision-making power is still controlled by state-owned enterprises, non-public capital will lose investment enthusiasm and its own mechanism vitality; if state-owned enterprises after the mixed ownership reform only blindly pursue the profit maximization, it may deviate from the reform objective of coordinated development of 
economic and social benefits and affect the comprehensive development of the economy adversely. Therefore, the effective integration of state-owned enterprises and non-public capital is the key to develop mixed ownership economy.

Second, the leadership system is different. Although the management system of state-owned enterprises has undergone many changes, state-owned enterprises are still affiliated units of government administrative organizations. The management system of non-public capital has undergone a series of changes after several decades of development, but it still does not get rid of the basic model of family management system. The parental system of the non-public capital has resulted in a strong exclusivity in its property rights, thus greatly increasing the costs of non-public equity transactions. The characteristics of the government administrative leadership system of the state-owned enterprises makes it difficult to get out of the government's administrative intervention and to become the real market subject.

The problem on willingness of state-owned enterprises to accept non-public capital. First, non-public capital lacks technological innovation. It is profit-driven with weak financial strength. In the early days of the establishment of non-public capital, it had no obvious advantages in the technology, personnel and information. It chose industries with simple technical requirement and relatively weak strength, so the technology development path shows a strong "copinism." This industry characteristic and development path directly cause the lack of technological innovation and weak financial strength of non-public capital. At the same time, non-public capital is profit-driven and there is a short-term behavior tendency. However, the input and output of state-owned enterprises demand high capital and technical strength and slow recovery of capital, such as the power production and supply industry, general and special equipment manufacturing industry, non-metallic mineral product industry and transportation equipment manufacturing industry. This is the main reason why it is difficult for non-public capital to participate in the mixed ownership reform of state-owned enterprises.

Second, some fields and industries of state-owned enterprises are not open to the mixed ownership capital. With the introduction of Decision of the Central Committee of the Communist Party of China on Some Major Issues Concerning Comprehensively Deepening the Reform, some investment projects of state-owned enterprise gradually begin to accept non-public capital, but some fields of many state-owned enterprises are still not open to non-public capital at present. The reason is that some state-owned enterprises still hope that they can monopolize the market and enjoy high monopoly profits by virtue of its possession of government administrative resources.

The loss of state-owned assets can be divided into the following categories: first, the assessment inconsistent with the facts causes the loss of state-owned assets; second, non-market-oriented business behavior causes the loss of state-owned assets; third, non-public capital occupies state-owned assets in system reform and bankruptcy; fourth, state-owned enterprises lose the management right in the joint venture and cooperation; fifth is the management level or workers embezzle state-owned assets. Mixed ownership reform may face the risk of the loss of state-owned assets. The lack of legal system and regulatory system is the root cause of the loss of state-owned assets in mixed ownership reform. The imperfect system and institution make the property right and responsibilities of state-owned enterprises unclear, which leads to that the state-owned asset management departments can not conduct effective supervision. According to the principal-agent theory, if the relevant regulatory measures are not in place and the agent is more informative than the client in the management, or the agent can get more profits with fewer risks by the non-standard reform, this conflict will become a reality. It will directly cause the problem that the agents damage the national interests and state-owned assets will lose. 


\section{Suggestions to Promote Mixed Ownership Reform of State-owned Enterprises}

Basic principles of mixed ownership reform of state-owned enterprises. First, the goal is to strengthen the state-owned economy and unleash the corporate vitality. On one hand, after the mixed ownership reform, the strength of state-owned enterprises should continue to grow and develop and its control or influence should be enhanced; on the other hand, the mixed ownership reform of state-owned enterprises make the state-owned enterprise independent subject in market. The reform should avoid the so-called mixed ownership reform and the market rules should be applied to the mixed ownership system, so that non-public capital can really participate in the development of state-owned enterprises. Then, they can participate in the enterprise market decisions, which will give full play to its advantages of flexible operating mechanism and high economic efficiency.

The second is to create a fair, transparent and competitive reform environment. Persisting in principles of equality of rights, equality of opportunity and equality of rules to create a fair, transparent and competitive reform environment is the institutional demand of market reform. The key to the ownership system reform is to form a mechanism to promote the growth and the competitiveness of enterprises. However, the market system in China is not perfect. The openness of the market, the fairness of competition and the transparency of operation need to be improved. Therefore, the reform needs fair, transparent and competitive basic ideas in the environment to fundamentally straighten out the market-oriented system, improve the efficiency of factor allocation and eliminate market segmentation and local protection, which will accelerate the formation of a unified, open, competitive and orderly market system. This will make the decisive role of the market in resource allocation in the mixed ownership realized.

Specific measures in mixed ownership reform of state-owned enterprises. First is to transform the government functions and strengthen asset evaluation to prevent the loss of state assets. On one hand, the reform requires state-owned assets supervision and management departments to transform functions and improve the state-owned assets management system to strengthen state-owned assets supervision which focuses on the capital management. Moreover, relevant departments should implement a comprehensive budget management and improve the operating representative reporting system to establish a good mechanism to prevent state-owned the loss of state-owned assets and ensure the preservation and appreciation of state-owned assets. On the other hand, relevant departments should strengthen asset management and enhance the administrative supervision in the aspects of management system development, the practice rules update, the implementation supervision of laws and the illegal acts punishment. Furthermore, they should strengthen the industry self-regulation in terms of qualification system, improvement of assessment ability, report appraisal, internal supervision of the industry and reports on irregularities. The administrative supervision and industry self-regulation can straighten out the management system of asset management industry and strengthen the legal responsibility of asset appraisal parties to prevent the asset evaluation from being a legal means of the loss of state-owned assets.

Second is to improve relevant policies to protect relevant rights of the non-public capital. It is proposed to speed up the development of specific methods for non-public capital into the franchise areas and introduce the scope, operation form and duration, application procedures, rights and obligations for non-public capital into the franchise areas. At the same time, relevant departments should carry out the reform of state-owned asset supervision system, regulate the governance requirements of mixed ownership enterprises and promulgate relevant policies to attract non-public capital. In addition, they should use the legal and regulatory system to eliminate implicit access restrictions for non-public capital, protect relevant rights of the non-public capital and promote the mixed ownership reform of state-owned enterprises smoothly.

Third is to break the monopoly drawbacks. In the process of mixed ownership reform, relevant departments should speed up the cancellation of improper access restrictions in some areas and truly solve the problems that state-owned enterprises set restrictions in the name of openness and hire some 
retired administrative people in the implementation. It is advisable to speed up the research and implementation of the reform of various industries, and actively introduce competition to promote the rapid development of industries. At the same time, they should further deepen the reform of the administrative examination and approval system, simplify the examination and approval procedures, comprehensively make the government affairs public, strengthen the social supervision and enhance the accountability, so as to break administrative drawbacks of the lack of overall situation and focus on the interests from the perspective of ideology and mechanism, which will help improve resource allocation efficiency and promote the continuous improvement and optimization of the environment.

Fourth is to implement the reform program step by step. It is suggested that the reform plan should be implemented according to the principles of "pilot first, from the easy to the difficult, step by step, stratified advance" and in accordance with the necessity and feasibility of the opening of the industry. At this stage, it is possible to choose suitable state-owned enterprises in the competitive field as pilots to carry out mixed ownership reform, because these enterprises are the closest to the market and the reform resistance is relatively small. Furthermore, it is helpful to sum up the relevant reform experience and lay a solid foundation for the second stage of the reform steadily. After owing the experience in the first stage, the reform should be gradually extended to non-competitive areas of state-owned enterprises. Relevant departments should strive to complete the mixed ownership reform of state-owned enterprises by 2020. Except for solely state-owned enterprises stipulated by the state policy, it is necessary for enterprises to realize the diversification of investment subjects and play the decisive role of the market in the resources allocation.

\section{Acknowledgement}

This paper was supported by the following project:

Key Project of National Social Science Foundation: Study on the state owned budget expenditure when the proportion of dividends paid by state-owned enterprises is doubled and redoubled(14AGL007);

Youth Project of National Social Science Foundation: Research on dividend distribution of state owned enterprises on the perspective of public resource revenue sharing(13CGL024);

Research project of Education Ministry Humanities and Social Sciences: Structure and performance evaluation of state owned capital operating budget under the guidance of people's livelihood finance(13YJA630007).

Social science research project of Minjiang University: Game model of government, enterprise and public interest in the dividend distribution of state owned enterprises(YSY13009).

\section{References}

[1] He Lu. A Study on Current Research Situation, Problems and Prospects of Mixed Ownership Reform in State-owned Enterprises [J]. Journal of Jixi University, 2016, (10): 62-64..

[2] Wang Kaiyong. A Discussion on the Path and System Design of Mixed Ownership Reform in State-owned Enterprises [J]. Shanghai Gas, 2016, (03): 33-39.

[3] Tang Zhaoxia. A Discussion on Problems and Countermeasures in Mixed Ownership Reform of State-owned Enterprises [J]. Theoretical Investigation, 2016, (03): 98-101.

[4] Wu Huangwu, Weng Lina.A Research Overview on Mixed Ownership Reform of State-owned Enterprises [J]. Manager' Journal, 2016, (12): 203.

[5] Wen Guolin, Qing Song. An Analysis on Problems and Countermeasures in Mixed Ownership Reform of State-owned Enterprises [J]. China Collective Economy, 2015, (34): 60-62. 
[6] Yang Hongying, Tong Lu. A Study on the Internal Governance of State-owned Enterprises in Mixed Ownership Reform [J]. Technoeconomics and Management Research, 2015, (05): 50-54.

[7] Yang Hongying, Tong Lu. A Discussion on Governance of State-owned Enterprises in Mixed Ownership Reform [J]. Macroeconomic Research, 2015, (01): 42-51. 